OOPEN ACCESS

International Journal of Applied Research in Social Sciences

P-ISSN: 2706-9176, E-ISSN: 2706-9184

Volume 2, Issue 6, P.No. 166-186, December, 2020

Fair East Publishers

Journal Homepage: www.fepbl.com/index.php/ijarss

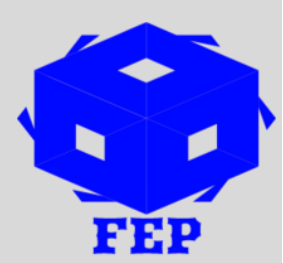

FEP

\title{
TEACHERS FEEDBACK AND ITS IMPACT ON STUDENTS ACADEMIC PERFORMANCE IN GHANA: A CASE STUDY OF NEW EDUBIASE SENIOR HIGH SCHOOL
}

\author{
Justice Agyei Ampofo ${ }^{1,2}$ \\ ${ }^{1}$ University for Development Studies, Tamale (Ghana) \\ ${ }^{2}$ University of Education, Winneba (Ghana)
}

*Corresponding Author: Justice Agyei Ampofo

Corresponding Author Email: papajusty@gmail.com

Article Received: 10-11-20 Accepted: 13-12-20

Published: 30-12-2020

Licensing Details: Author retains the right of this article. The article is distributed under the terms of the Creative Commons Attribution-Non Commercial 4.0 License (http://www.creativecommons.org/licences/by-nc/4.0/) which permits non-commercial use, reproduction and distribution of the work without further permission provided the original work is attributed as specified on the Journal open access page.

\begin{abstract}
The purpose of the study was to investigate how feedbacks from teachers affect the academic achievement of New Edubiase Senior High School students in the Adansi South District of Ghana. The descriptive survey design was employed for this study. The researcher used questionnaire as the main instruments for data collection. The target population for the study was all the teachers and students of New Edubiase Senior High School. In all, 60 teachers and 60 students were used for the study. Simple random and purposive sampling strategy was employed to select respondents for the study. Percentages were used for the analysis of the response and presented in tables and charts. Findings showed that students of New Edubiase Senior High School are aware of the importance of teachers' feedback, both formal and informal type of formative assessment is used in assessing students of New Edubiase Senior High School by their teachers but the type of formative assessment that is mostly used in assessing students is formal. The study also found out that feedback help students to know the benefit of learning, encourages students to be more active and participate in class activities, help students to internalize and process the demands of task given to them by their teachers, increases self-esteem of students, guides students in on their performance, feedback deepen the understanding of students on their performance and also clarify what students should do. The study concluded that feedback can be used as an effective teaching tool by teachers in improving students' academic achievement. Based on the findings, it was recommended that
\end{abstract}


teachers of New Edubiase Senior High School should use formative feedback effectively as an effective tool on student learning and achievement and must also see the importance of assessment and clearly show how feedback can have a positive impact on student learning. .

Keywords: Teachers Feedback, Impacts, Senior High School Students, Academic Performance, New Edubiase.

\section{INTRODUCTION}

Academic performance of students has always been a subject of interest to every educational institution. Whereas there is a consensus that schools should play a major role in this process, there seems to be disagreement about what exactly that role should be. While some believe that the primary focus of schools should be the academic preparation of students (Ampofo, 2019), others however believe that, effort of schools should be integrated with other social institutions such as family and community towards educating children (Linn \& Miller, 2005). In fact, teachers' feedback on students' academic performance (Ampofo, 2019), should efficiently and effectively be of great concern to all educationist.

Researchers over the years have used a variety of ways to measure academic performance and these include report card grades, grade point averages, standardized test scores, teacher ratings, other cognitive test scores, grade retention and dropout rates (Shute, 2007). Thus students' academic performance is typically assessed and teachers give feedback at the end of the assessment to students. It is widely recognised that feedback is an important part of the learning cycle, but both students and teachers frequently express disappointment and frustration in relation to the conduct of the feedback process (Ajogbeje, 2012; Ampofo, 2019). Students may complain that feedback on assessment is unhelpful or unclear, and sometimes even demoralizing.

The classroom assessment environment as perceived by students is of increasing interest to the educational assessment community. Many educators have claimed that assessment-related activities used in the classroom convey important information about what is valued there, and hence have an influence on students' academic performance (Wiliam \& Thompson, 2007). Students' achievement goals have been regarded as important achievement-related outcomes to be promoted in the classroom learning process (Brookhart, 2012).

The relationships that teachers develop with their students have an important role in a students' academic growth. Brookhart (2012) writes; "learning is a process that involves cognitive and social psychological dimensions, and both processes should be considered if academic achievement is to be maximized.". In formative evaluation the student takes diagnostic tests at several points in the course of his or her studies and on the basis of test results (feedback) is obtained (Hattie, 2003). There is the likelihood that if students' learning is adequately evaluated regularly during the teaching-learning process and prompt feedback is provided, students' level of performance will improve.

However, not all feedback is the same and not all feedback is equally effective in promoting learning (Hattie, 2009). The basic goal of this present study is to investigate how teachers can use feedback to enhance students' academic achievement of Senior High School students in Ghana using New Edubiase Senior High School as a case study. 
A preliminary survey by the researcher in New Edubiase Senior High School shows that teachers focus on traditional assessment methods such as the test, examinations, quizzes and other formal methods. Assessment is not focused for learning but assessment of learning with the main focus being examinations. Students are learning by rote and are not making meaningful connection between what they know and everyday occurrence which will allow them to make connections with the material. This results in some subjects being difficult to them.

Informal observations by the researcher in New Edubiase Senior High School indicate that most teachers use a lot of feedback forms in their formative assessment to help students do corrections of their mistakes and the students do complain a lot about such feedbacks. Thus, during the researcher's stay on the Campus of New Edubiase Senior High School he met some students who narrated their ordeals as Senior High School students with regard to the effect of their teachers' feedback on their academic achievement. While some said the feedback helped them to correct their mistakes others said it demoralized them and hence they lose interest in the subject. Interestingly, the situation is not different in most Senior High Schools in Ghana. The question now is; do all teachers use feedback as a formative assessment tool in enhancing students learning or not? The main purpose of the current study is to investigate how feedback from teachers can help to improve the academic performance of students.

\section{LITERATURE REVIEW}

\section{Definition of Feedback}

Drawing from theories of classroom psychology, Hattie (2012) provides a generic definition of the term feedback. For him, feedback appears when, "the output of a system becomes an input to the same system causing the system to respond dynamically to its previous products." That is to say, feedback does not occur randomly, but it is rather part of a complex system of other subsystems which are interrelated and mutually influenced by each other.

Havnes et al (2012) consider feedback as a social act since it embraces all the aspects (context, participants, medium, and goal) that, together, give any communicative act its identity. For them, like other communicative acts, feedback occurs in a context of a particular kind (institutional, pedagogical); it appears between participants of particular identities (teacher/peer/learner); it is delivered by a particular medium (peer, conference, written comments) and it is designed to accomplish certain educational, pedagogical and social purposes. A consideration of all these aspects would, therefore, contribute to an appropriate interpretation of feedback.

\section{The impact of teachers' feedback on academic achievement of students}

A key feature in effective use of feedback is that it must encourage "mindfulness" in students' responses to the feedback (Shute, 2007). Similarly, Rakoczy et al (2013) analysis found substantial variability in the effects of feedback. They reported that feedback about a particular task and how to do it is more effective than feedback that focuses on praise or on punishments and rewards.

Hattie (2012) emphasized that feedback needs to address the questions of what the goals are, where the student currently stands in relation to those goals, and what the next steps should be for reaching the goals. They also noted that feedback focused on the level of the task, the 
processes required to complete the task, and self-regulatory task-related activities are more effective than is feedback focused on the person (typically, praise).

Finally, Sendziuk (2010) argued that, 'feedback has to prompt active information processing on the part of the learners.' The key to understanding the effects of feedback as it occurs via formative assessment in formal learning settings has to do with what Strijbos, Narciss and Dunnebier (2010) call the mindfulness with which it is received or what Hattie (2012) call actively processing the information. Unless students successfully process the feedback that they receive, there is little reason to believe that the feedback will have a positive effect on learning. But most research on feedback links feedback directly to subsequent achievement without considering the degree to which the feedback is successfully interpreted and processed.

Students in Senior High Schools in Ghana typically receive some level of feedback on the specifics related to their performance (Thurlings et al, 2013). The response that students receive often serves as a summary of their performance and provides information on how they can improve. The use of formative assessment to enhance student achievement has undergone a renaissance in recent years, leading to a variety of studies examining aspects of the relationship between formative assessment and students' ability to profit academically from such assessment (Wiliam \& Thompson, 2007).

In New Edubiase Senior High School, the effectiveness of written comments that focus on error correction is deemed dubious, and the question of whether such feedback is beneficial to writing development is a controversial one. According to Yates \& Kenkel (2002); Ferris (2003) and Hyland (2003), because writing is meant to be primarily meaningful, any attempt to separate language forms from their meanings is deemed a false one. Therefore, instead of abandoning error correction altogether or delaying it to later drafts, many composition researchers (example Shute (2007); Strijbos et al (2010); Ajogbeje (2012); Wiggins (2012)); Thurlings et al (2013) suggest that feedback should be selective, building on what is presently significant to students and giving attention to what has been taught in the classroom.

In this research, the researcher is interested in finding out how teachers feedback at New Edubiase Senior High School in the Ashanti Region of Ghana can help improve the academic performance of students. This will therefore help to know how teachers' feedback can be used to improve academic achievement of students in the New Edubiase Senior High School.

\section{METHODOLOGY}

\section{Research Design}

The purpose of the study was to investigate how feedbacks from teachers affect the academic achievement of New Edubiase Senior High School students. The research is a descriptive survey through which views and opinions were sampled from teachers and students. Ampofo (2020) views descriptive survey as a design that portrays accurately the characteristic of particular individual situations or groups. In other words, the descriptive survey is a research method that is non-experimental and deals with the relating among non-manipulated variable. A descriptive survey also provides a quantitative or numeric description of trends, attitudes, or opinions of a population by studying a sample of that population. It includes cross-sectional and longitudinal studies using questionnaire or structured interviews for data collection, with the intent of generalizing from a sample to a population (Kusi, 2012; Ampofo, 2020). 
The descriptive survey was considered the most appropriate design for conducting this research because information gathered from the descriptive research can be meaningful or useful in diagnosing a situation since it involves describing, recording, analyzing and interpreting conditions that exist. The descriptive survey was again considered the most appropriate design for conducting this study because it is the one that deals with things as they currently are (Creswell, 2013; Ampofo, 2020).

\section{The Study Area}

The study was conducted in New Edubiase Senior High School. It is one of many Senior High Schools within the Ashanti Region of Ghana. The researcher's work experience has helped him gain access to the information needed for the successful completion of this study. The school is within his locality hence reducing the cost as well as risk involved in travelling to the school. This makes the data collection process easy and convenient.

\section{Population}

The target population consisted of all the teachers and students of New Edubiase Senior High School. The school has a teacher population of about 90 teachers. The school has a student population of about 1200 . The teachers were selected because they assess students' work, give feedback on their assessment and interact with students in many different ways and could provide useful information for the study. The students themselves are those who are affected by teachers' feedback.

Table 1

Sample Size

\begin{tabular}{lll}
\hline & Teachers & Students \\
\hline Population & 90 & 1200 \\
Sampled & 60 & 60 \\
\hline \multicolumn{3}{c}{ Source: Field Survey $(2020)$}
\end{tabular}

\section{Sample Size and Sampling Techniques}

Stratified simple random sampling was used. According to Ampofo (2020), is a variation of simple random sampling in which the population is partitioned into relatively homogeneous group called strata and a simple random sampling is used to select from each stratum. (Ampofo, 2019), argued that a representative sample of $10 \%$ and above is enough for providing the required information in large population. The students were put into two (2) strata, thus SHS 2 and 3. Simple random sample technique was then used to select thirty (30) students from SHS 2 and 3 totally 60 students. All the students were given equal chance to pick from a folded pieces of papers on which "YES or NO", was written and those who selected "YES" were taken to represent that class.

Also teachers were given equal chance to pick from a folded pieces of papers on which ''YES or NO', was written and sixty (60) who selected 'YES', were taken to represent that class because they assess, evaluate, give feedback and interact with students in many different ways and could provide useful information concerning the study hence, purposive sampling was used to select the teachers.

\section{Instrumentation}

A Structured Questionnaire was used to collect data from respondents in this study. The questionnaire was both close ended and open ended questions with options like (Strongly Agree, Agree, Disagree, Strongly Disagree and Not Sure). It was divided into five sections 
which are as follows: Section A - Personal data and Section B - provides questions on the awareness of students about the importance of teachers' feedback, Section C on what teachers do to make students consider their feedback and Section D on the impact of teachers' feedback on students' academic achievement and Section E on how feedback can be used as an effective teaching tool by teachers in improving students' academic achievement.

\section{Pretesting of the Instrument}

A pilot study was conducted in St. Andrews Senior High School which has the same sociodemographic structure as that of New Edubiase Senior High School. The questionnaires were administered to twenty (20) students and twenty (20) teachers. The pilot study was done to improve the reliability of instrument. Changes were made to questions deemed inappropriate after the pilot study.

\section{Validity of the Instruments}

A research instrument is said to be valid when it measures what it is supposed to measure. Colleagues' comments are in relation to the misunderstanding and misinterpretation of the question. This was checked by way of employing pretesting method. Content validity on the other hand, refers to the capacity of the instrument to prove adequate coverage of a topic. Adequate preparation of the instrument under guidance of expert opinion and pre-testing of the question helped established the content validity.

\section{Reliability of the Study}

Reliability has to do with an instrument consistently producing the same result every time it is used (Ampofo, 2019). The test retest method was used to test for the reliability of the instrument. The questionnaires were administered to students and teachers of St. Andrews Senior High School which has the same socio- demographic as that of New Edubiase Senior High School. The same questionnaires were administered to them after two weeks. A correlation coefficient of 0.8 alpha levels was obtained which is considered reliable.

\section{Data Collection Procedure}

The researcher obtained permission from the Head master of New Edubiase Senior High School to seek their approval and access to the school, students and other documents that would facilitate the study. The Head master of the school conveyed a meeting with teachers and students to inform them about the purpose of the research and their cooperation. The participants were told of the purpose, time, venue and how to answer the questionnaires. They were also assured of their confidentiality and anonymity. The researcher self-administered the questionnaires to the respondents to avoid delay and any inconsistencies in questionnaire administration.

\section{Data Analysis Technique}

Analysis of data provided facts and figures that enabled interpretation of the results and reaching conclusions from the findings of the study. All items of the questionnaires were coded. Items in the form of Likert scale were rated between $5-1$, with 5 being the highest and 1 being the lowest. Questionnaires were edited to ensure that clear, legible, relevant, and appropriate responses had been provided. The coded items and their corresponding frequencies were fed into the computer using the SPSS software programme. Data were analyzed using simple percentages and frequencies. 


\section{Introduction}

\section{RESULTS AND DISCUSSION OF RESULTS}

The purpose of the study was to investigate how feedbacks from teachers affect the academic achievement of New Edubiase Senior High School students. This was done through the use of structured questionnaire in the data collection process. In analyzing the results of the data collected through the study, the researcher has divided this chapter into the following subdivisions:

i. Biographical data

ii. Students' awareness of the importance of the teachers' feedback.

iii. The forms of feedback given to students by the teachers.

iv. The impact of teachers' feedback on students' academic achievement

\section{Demographic Characteristics of Respondents (Teachers)}

One item of the questionnaire gathered data on the respondents (teachers) gender which is presented in the table below.

Table 2

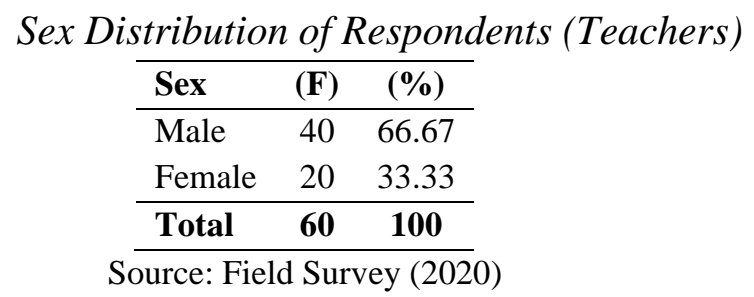

The sex distribution of teachers' respondents show that majority of respondents were males as males represented as $40(66.67 \%)$ and $20(33.33 \%)$ were females. The implication is that, male respondents outnumbered female respondents. This finding is in disagreement with Ampofo (2019) who reveal that, most female teachers are in teaching in urban areas of Ghana. The findings of this study is also in disagreement with a study by Ajogbeje (2012) who asserted that it could be partly due to female teachers joining their husbands who work in urban areas hence avoid working in rural areas.

Another aspect of the questionnaire gathered data on the age distribution of teachers' respondents and this is what Table 3 presents.

Table 3

\begin{tabular}{|c|c|c|}
\hline \multicolumn{3}{|c|}{ Age of Respondents (Teachers) } \\
\hline Age Range & (F) & $(\%)$ \\
\hline 18-23yrs & - & - \\
\hline $24-29 \mathrm{yrs}$ & 2 & 3.33 \\
\hline $30-34 \mathrm{yrs}$ & 8 & 13.33 \\
\hline 41-45yrs & 10 & 16.67 \\
\hline 46-50yrs & 40 & 66.67 \\
\hline $51-55 \mathrm{yrs}$ & - & - \\
\hline $56-60$ & - & - \\
\hline Total & 60 & 100 \\
\hline
\end{tabular}


The results form Table 3 shows that majority of respondents were between the age group 4650 representing $40(66.67 \%)$, followed by those between the age group of 41-45 representing 10 (16.67\%), followed by those between the age group 30-34 representing 8 (13.33\%), followed by those between the age group 24-29 representing 2 (3.33\%). The implication is that, majority of the teachers teaching in New Edubiase Senior High School were older form 30 years.

Another aspect of the questionnaire gathered data on the teaching experience of teachers' respondents and this is what Table 4 presents.

Table 4

\begin{tabular}{|c|c|c|}
\hline \multicolumn{3}{|c|}{ Teaching experience } \\
\hline Range of Years & Frequency & Percentage \\
\hline 1 month - $2 y r s$ & - & - \\
\hline $2 \mathrm{yrs}-3 \mathrm{yrs}$ & 2 & $3.33 \%$ \\
\hline $4 y r s-5 y r s$ & 8 & $13.33 \%$ \\
\hline Above 5yrs & 50 & $83.33 \%$ \\
\hline Total & 60 & $100 \%$ \\
\hline
\end{tabular}

From Table 4, the most opted number of years of teaching experience was above 5 years. Majority of the teachers $50(83.33 \%)$ had teaching experiences above five years, $8(13.33 \%)$ for 4 - 5 years and $2(3.33 \%)$ for the $2-3$ years of teaching. It can be assumed that, all the teachers in New Edubiase Senior High School have adequate work experience and can provide reliable information for the study.

Table 5

Highest Level of Education Attained (Teachers)

\begin{tabular}{lcc}
\hline Response & Frequency & Percent \\
\hline Diploma & - & - \\
First Degree & 35 & $58.33 \%$ \\
Masters & 25 & $41.67 \%$ \\
\hline Total & $\mathbf{6 0}$ & $\mathbf{1 0 0 . 0}$ \\
\hline \multicolumn{2}{c}{ Source: Field Survey (2020) }
\end{tabular}

Table 5 shows that $35(58.33 \%)$ the teachers respondents had a first degree with the remaining 25 (41.67\%), have a master degree. A deduction from the above is that majority of the respondents are having degree teaching at New Edubiase Senior High School.

One aspect of the questionnaire also gathered data on subject taught by the teachers' respondents and this is what figure 1 presents.

From Figure 1, it can be shown that majority of the teachers respondents $8(13.33 \%)$ respectively each indicated that are teaching English Language, Core Mathematics and Core Science, $5(8.33 \%)$ respectively each indicated that they are teaching Social Studies and Government, $3(5.0 \%)$ respectively each indicated that they are teaching Geography, Literature, Economics, Business Management, French, Accounting, Costing and Management in Living while $2(3.33 \%)$ indicated that they are teaching History. The implication of this is that all the teachers teaching respective subjects were included in the study as such may give relevant information concerning their assessment feedback and how it affects students' academic performance. 


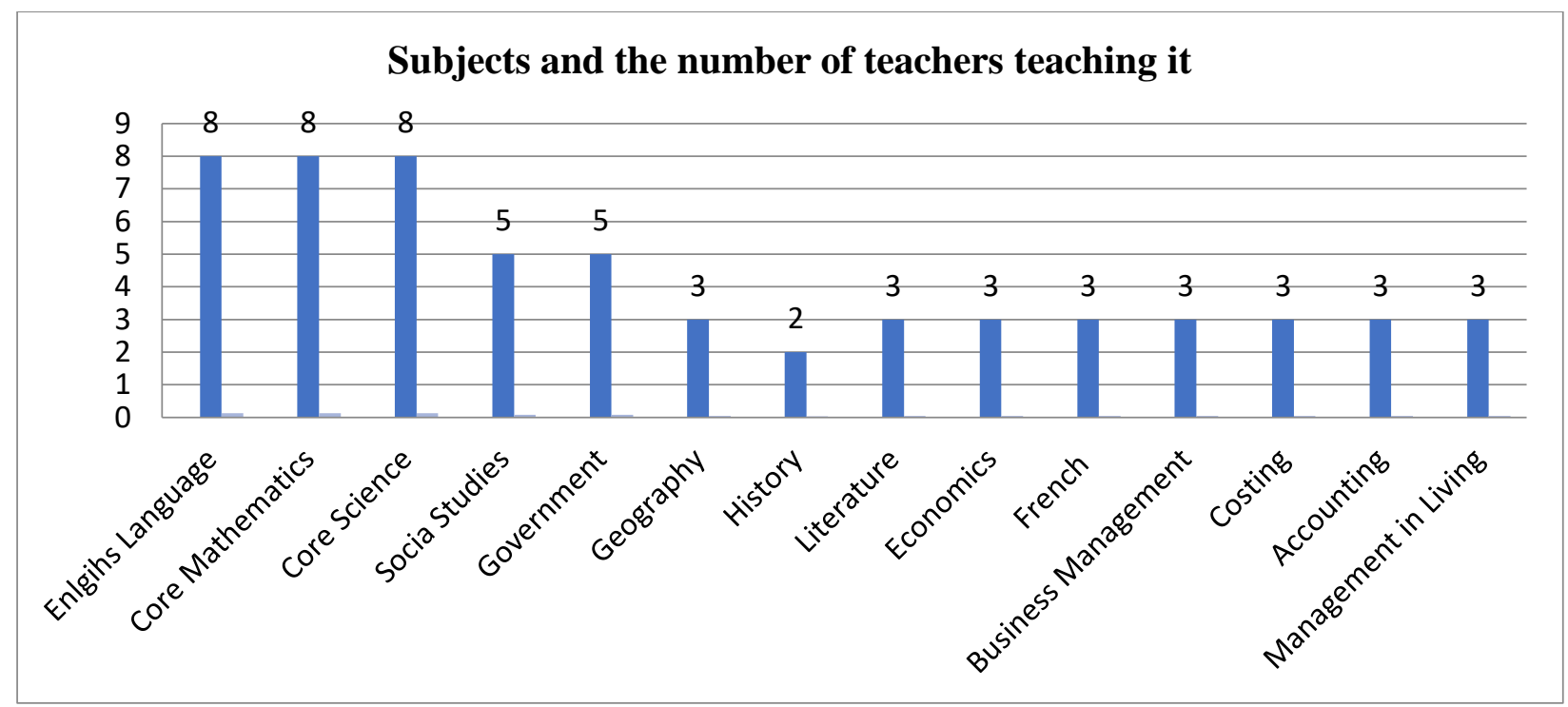

Figure 1: Subject taught by Respondents (Teachers)

Source: Field Survey (2020)

\section{Demographic Characteristics of Study Students Participants}

One item of the questionnaire gathered data on the respondents (students) gender which is presented in the table below.

Table 6

Gender and Age of students

\begin{tabular}{cccccc}
\hline & Gender & \multicolumn{5}{c}{ Age } \\
\hline & Frequency & Percentage & Age Range & Frequency & Percentage \\
\hline Males & 30 & $50.0 \%$ & $12-14$ & 10 & $16.67 \%$ \\
Females & 30 & $50.0 \%$ & $15-16$ & 15 & $25.0 \%$ \\
Total & 60 & $100 \%$ & $17-19$ & 30 & $50.0 \%$ \\
& & & 20yrs and above & 5 & $8.33 \%$ \\
\hline
\end{tabular}

Source: Field Survey (2020)

Out of the sixty (60) students sampled from Accra Senior High School majority of the students $30(50.0 \%)$ were males whiles $30(50.0 \%)$ were females. The implication of this is that both male' and female students dominated were equally represented in the study. Also 30 $(50.0 \%)$ of the students who took part in the study were between the ages of 17-19, followed by $15(25.0 \%)$ who were between the ages of 15-16, followed by 10 (16.67\%) who were between the ages of $12-14$, followed by $5(8.33 \%)$ who were 20 years and above. The lowest age was 20 years and above and the highest age was 17-19 years. Most of the students who participated in the study were within the school going age.

Table 7

\begin{tabular}{lll} 
Programme Offered by Students \\
\hline Programme & $(\mathbf{F})$ & $\mathbf{( \% )}$ \\
\hline General Arts & 24 & 40.0 \\
Agriculture Science & 9 & 15.0 \\
General Sciences & 5 & 8.33 \\
Business & 9 & 15.0 \\
Home Economics & 11 & 18.33 \\
Visual Arts & 7 & 11.67 \\
\hline Total & $\mathbf{6 0}$ & $\mathbf{1 0 0}$ \\
\hline
\end{tabular}

Source: Field Survey (2020) 
Table 7 presents the programmes offered by the respondents who responded to the questionnaire. It pointed out that out of the total respondents of $60,24(40.0 \%)$ of the respondents study General arts, followed by Home Economics with 11 students representing $(18.33 \%)$ of the total respondents, 9 students representing $(15.0 \%)$ respectively each offer Agriculture Science and Business, 7 students representing (11.67\%) of respondents offer Visual Arts and 5 (8.33\%) offer Agricultural Science. This clearly indicates that majority of the students offer general arts than other courses.

\section{Analysis of Items}

\section{Research Question 1: What is the importance of teachers' feedback on lessons to the students at New Edubiase Senior High School?}

One aspect of the questionnaire gathered data on the techniques of assessing the students of New Edubiase Senior High School by their teachers and the relevant data are presented below.

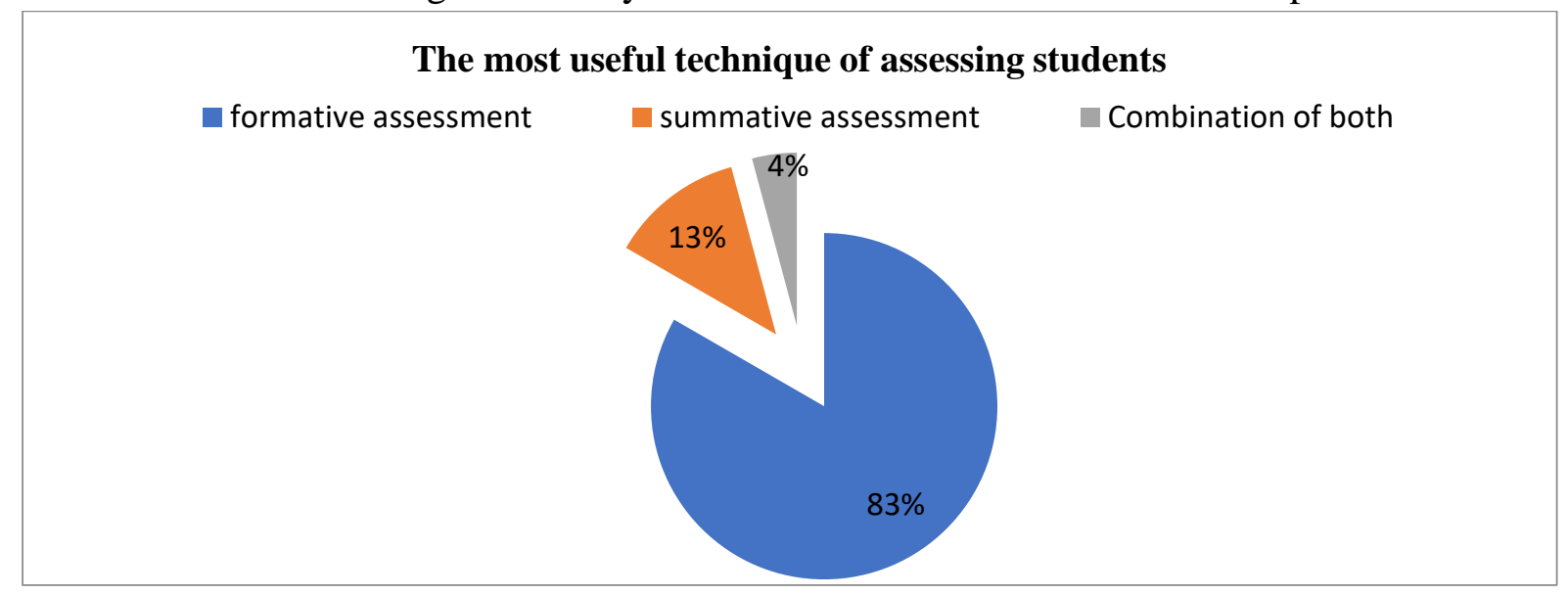

Figure 2: The most useful technique of assessing New Edubiase Senior High School students Source: Field Survey (2020)

From Figure 2, majority of the respondents 100 out of 120 representing (83.33\%) indicated that the most useful technique of assessing students is formative assessment, followed by 15 $(13 \%)$ who indicated that it is summative assessment whiles $5(4 \%)$ who indicated that is combination of both formative and summative assessment. The implication of the above result means that the most useful technique by teachers in New Edubiase Senior High School in teaching their students is formative assessment.

The above result is consistent with a study by Sommers (1992) who asserted that formative feedback over the summative one for grades are seen as an end in themselves and scarcely contribute to writing improvement. According to Harmer (2004)) teachers always used feedback that is selective, building on what is presently significant to students and giving attention to what has been taught in the classroom.

One aspect of the questionnaire also gathered data on the most effective type of formative assessment used by teachers of New Edubiase Senior High School by assessing their students and the relevant data is presented below. 


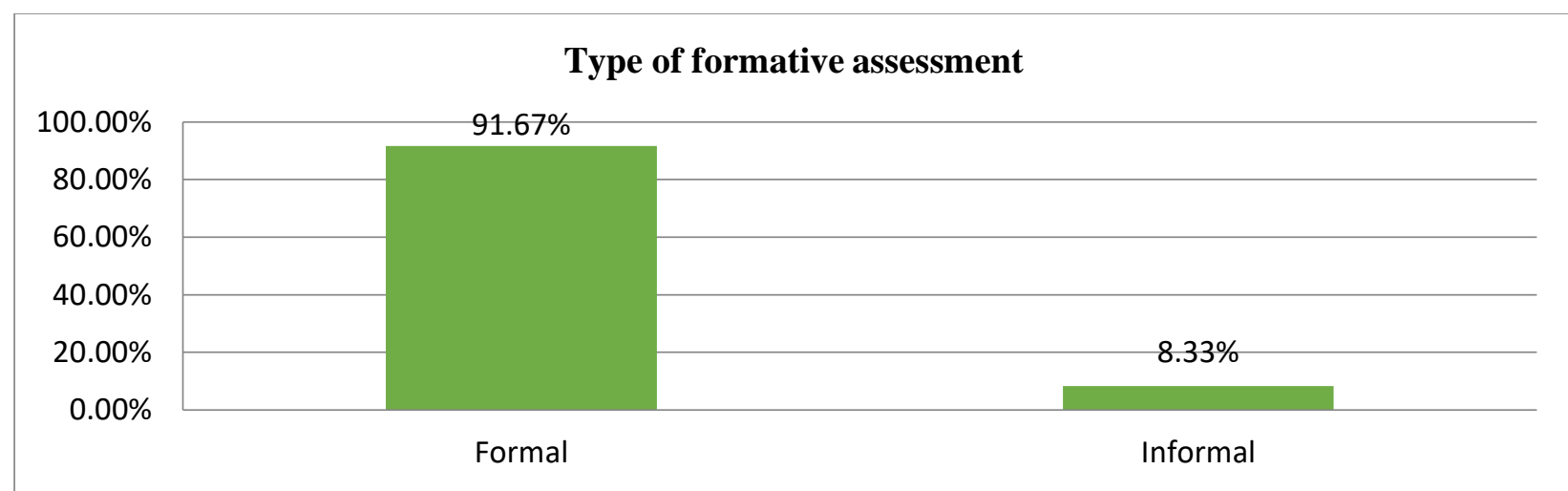

Figure 3: The most effective type of formative assessment

Source: Field Survey (2020)

From Figure 3 above, majority of the respondents 110 out of 120 representing (91.67\%) indicated that the most effective type of formative assessments in terms of boosting students' academic achievement is formal whiles $10(8.33 \%)$ indicated that the most effective type of formative assessments in terms of boosting students' academic achievement is informal. The implication of this result means that teachers of New Edubiase Senior High School use formal assessment in boosting their students' academic achievements. This result is consistent with a study by Brookhart (2012) who posited that formal assessment of students has an effect of permitting learners to enhance their comprehension quality and promoting knowledge execution and skill. According to Hattie (2012) formal assessment is more effective and resulted in better improvement of students' academic performance.

One aspect of the questionnaire also gathered data from respondents on how teachers give feedback after assessing students and relevant data is presented below.

Table 8

Teachers Feedback After Assessment of Students

\begin{tabular}{|c|c|c|c|c|c|}
\hline Item & Always & Sometimes & Rarely & Freq. & $\begin{array}{c}\text { Total } \\
(\%)\end{array}$ \\
\hline $\begin{array}{l}\text { 1. Are students provided with immediate feedback } \\
\text { after any sort of assessment }\end{array}$ & $\begin{array}{c}60 \\
(50.0 \%)\end{array}$ & $\begin{array}{c}48 \\
(40.0 \%)\end{array}$ & $\begin{array}{c}12 \\
(10.0 \%)\end{array}$ & 120 & $100 \%$ \\
\hline
\end{tabular}

Source: Field Survey (2020)

Table 8 shows how teachers of New Edubiase Senior High School give feedback on their students' assessment. The results show that majority of the respondents 60 out 120 representing (50.0\%) indicated that teachers always give feedback on students' assessment, 48 out of 120 representing (40.0\%) indicated that teachers sometimes give feedback on students' assessment while 12 out of 120 representing (10.0\%) indicated that teachers rarely give feedback after assessing students. The implication of this result means that teachers of New Edubiase Senior High School give feedback after assessing their students. The result of this study is consistent with a study by Linn and Miller (2005) who asserted that teachers written comments is the most common feedback delivering method for both teachers and students and which contribute to the overall improvement of student writing be it at form or content level. Some aspect of the questionnaire also gathered data from respondents on the importance of teachers' feedback on students' assessment. This is what table 9 presents. 
Table 9

The Importance Of Teachers' Feedback

\begin{tabular}{|c|c|c|c|c|c|}
\hline Feedback Importance & Agreed & Uncertain & Disagreed & $\mathbf{F}$ & $\%$ \\
\hline 1. It promote student learning & $\begin{array}{c}120 \\
(100.0 \%)\end{array}$ & - & - & 120 & 100 \\
\hline $\begin{array}{l}\text { 2. It help student to know the benefit of } \\
\text { learning }\end{array}$ & $\begin{array}{c}120 \\
(100.0 \%)\end{array}$ & & & 120 & 100 \\
\hline $\begin{array}{l}\text { 3. It encourages students to be more active } \\
\text { and participate in class activities }\end{array}$ & $\begin{array}{c}100 \\
(83.33 \%)\end{array}$ & - & $\begin{array}{c}20 \\
(16.67 \%)\end{array}$ & 120 & 100 \\
\hline 4. It help students to pay attention in class & $\begin{array}{c}80 \\
(66.67 \%)\end{array}$ & $\begin{array}{c}20 \\
(16.67 \%)\end{array}$ & $\begin{array}{c}20 \\
(16.67 \%)\end{array}$ & 120 & 100 \\
\hline $\begin{array}{l}\text { 5. It help students to internalize and process } \\
\text { the demands of task given to them by } \\
\text { their teachers }\end{array}$ & $\begin{array}{c}120 \\
(100.0 \%)\end{array}$ & - & - & 120 & 100 \\
\hline 6. It increases self-esteem of students & $\begin{array}{c}90 \\
(75.0 \%)\end{array}$ & $\begin{array}{c}10 \\
(8.33 \%)\end{array}$ & $\begin{array}{c}20 \\
(16.67 \%)\end{array}$ & 120 & 100 \\
\hline 7. It guides students on their performance & $\begin{array}{c}120 \\
(100.0 \%)\end{array}$ & - & - & 120 & 100 \\
\hline $\begin{array}{l}\text { 8. It deepens the understanding of students } \\
\text { on their performance }\end{array}$ & $\begin{array}{c}120 \\
(100.0 \%)\end{array}$ & - & - & 120 & 100 \\
\hline $\begin{array}{l}\text { 9. Influence learning and improve the } \\
\text { competence of Senior High School } \\
\text { teachers }\end{array}$ & $\begin{array}{c}90 \\
(75.0 \%)\end{array}$ & $\begin{array}{c}20 \\
(16.67 \%)\end{array}$ & $\begin{array}{c}10 \\
(8.33 \%)\end{array}$ & 120 & 100 \\
\hline $\begin{array}{l}\text { 10. Simplify and clarify what a student } \\
\text { should do }\end{array}$ & $\begin{array}{c}120 \\
(100.0 \%)\end{array}$ & - & - & 120 & 100 \\
\hline 11. It brings motivational value & $\begin{array}{c}30 \\
(25.0 \%)\end{array}$ & - & $\begin{array}{c}90 \\
(75.0 \%)\end{array}$ & 120 & 100 \\
\hline 12. Arouse interest of students & $\begin{array}{c}90 \\
(75.0 \%)\end{array}$ & - & $\begin{array}{c}30 \\
(25.0 \%)\end{array}$ & 120 & 100 \\
\hline $\begin{array}{l}\text { 13. Feedback provides reinforcement effect } \\
\text { and correctional information to students }\end{array}$ & $\begin{array}{c}120 \\
(100.0 \%)\end{array}$ & - & - & 120 & 100 \\
\hline $\begin{array}{l}\text { 14. Feedback informs students of their } \\
\text { successful academic performance }\end{array}$ & $\begin{array}{c}120 \\
(100.0 \%)\end{array}$ & - & - & 120 & 100 \\
\hline $\begin{array}{l}\text { 15. Feedback informs students of their poor } \\
\text { academic performance }\end{array}$ & $\begin{array}{c}60 \\
(50.0 \%) \\
\end{array}$ & - & $\begin{array}{c}60 \\
(50.0 \%) \\
\end{array}$ & 120 & 100 \\
\hline
\end{tabular}

Source: Field Survey (2020)

Table 9 reveals the importance of teachers' feedback on students' assessment at New Edubiase Senor High School. There were 15 items which provided responses on the importance of teachers' feedback. From the table all the respondents 120 (100\%) agreed that feedback promote student learning. Also all the respondents $120(100 \%)$ agreed that feedback help student to know the benefit of learning. In addition, majority of the respondents 100 $(83.33 \%)$ agreed that feedback encourages students to be more active and participate in class activities whiles $20(16.67 \%)$ disagreed that feedback encourages students to be more active and participate in class activities. Majority of the respondents $80(66.67 \%)$ agreed that feedback help students to pay attention in class, 20 (16.67\%) were uncertain that feedback help students to pay attention in class whiles $20(16.67 \%)$ disagreed that feedback help students to pay attention in class.

Also, all the respondents $120(100 \%)$ agreed that feedback help students to internalize and process the demands of task given to them by their teachers. Majority of the respondents 90 (75.0\%) agreed that feedback increases self-esteem of students, 20 (16.67\%) disagreed that feedback increases self-esteem of students whiles $10(8.33 \%)$ were uncertain that feedback increases self-esteem of students. 
Moreover, all the respondents $120(100 \%)$ agreed that feedback guides students on their performance. Also all the respondents $120(100 \%)$ agreed that feedback deepens the understanding of students on their performance. Majority of the respondents $90(75.0 \%)$ agreed that feedback influence learning and improve the competence of Senior High School teachers, 20 (16.67\%) were uncertain that feedback influence learning and improve the competence of Senior High School teachers whiles 10 (8.33\%) disagreed that feedback influence learning and improve the competence of Senior High School teachers.

Furthermore, all the respondents $120(100 \%)$ agreed that feedback simplify and clarify what a student should do. Majority of the respondents 90 (75.0\%) disagreed that feedback brings motivational value whiles $30(25.0 \%)$ agreed that feedback brings motivational value. Also majority of the respondents $90(75.0 \%)$ agreed that feedback arouse interest of students whiles $30(25.0 \%)$ disagreed that feedback arouse interest of students.

Moreover, all the respondents 120 (100\%) agreed that feedback provides reinforcement effect and correctional information to students. All the respondents 120 (100\%) agreed that feedback informs students of their successful academic performance. Also $60(50 \%)$ respectively each agreed and also disagreed that feedback informs students of their poor academic performance. The implication of all the above results from Table 9 means that feedback is very significant in student's assessment.

The above result is consistent with a study by Sendziuk (2010) who asserted that feedback has effects of permitting learners to enhance their comprehension quality and promoting knowledge execution and skill. The author further added that feedback is therefore deemed, as argued by Sendziuk (2010), an inseparable, integral and central element in language learning generally. The result of this study also confirms to the study by Wiggins (2012) who postulated that feedback arouse interest of students, brings motivational value, provides reinforcement effect and correctional information to students and informs students of their successful academic performance.

One aspect of the questionnaire also gathered data on how is feedback provision important in teaching of writing. This is what Figure 4 presents.

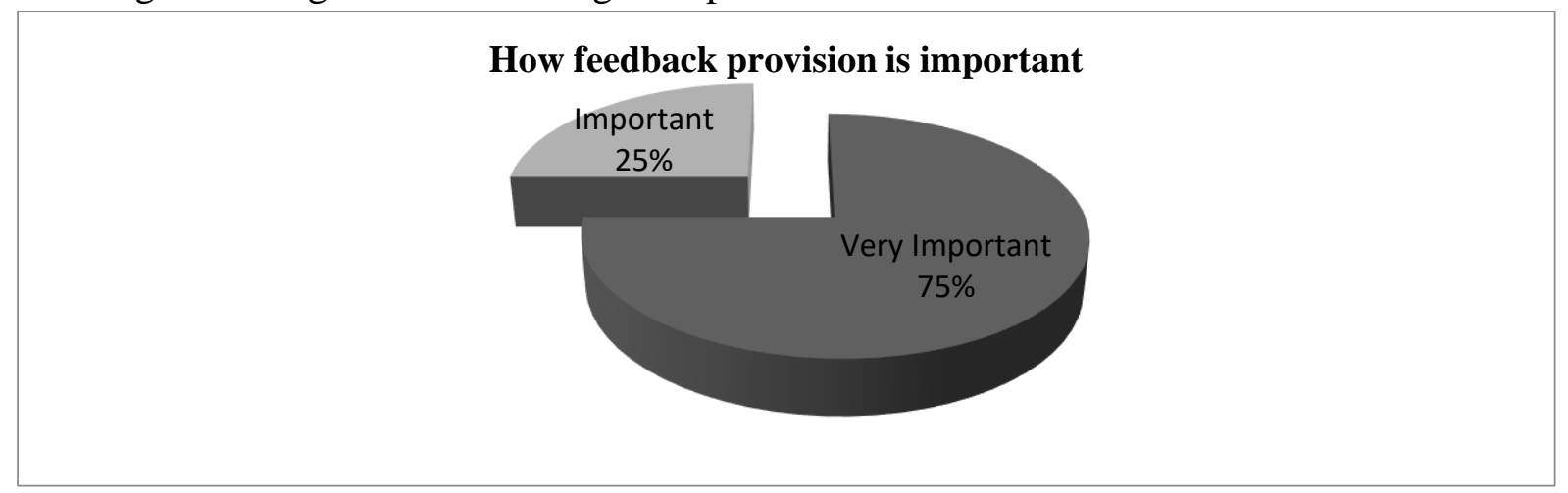

Figure 4: How feedback provision important in teaching of writing

Source: Field Survey (2020)

From Figure 4, majority of the respondents 90 (75.0\%) indicated that feedback provision is very important in teaching of writing whiles $30(25.0 \%)$ indicated that feedback provision is important in teaching of writing. The implication of this is that feedback is very relevant in teaching and learning to teachers and students of New Edubiase Senior High School. This result is consistent with a study by Shute (2007) who asserted that feedback is an important 
part of the learning cycle. Wiggins (2012) opined that a person who is informed of his successful performance on a test would begin to develop interest in that subject and may continue to explore means of doing well in subsequent tasks.

One aspect of the questionnaire also gathered data on how feedback effects on revision and students learning and this is what Figure 5 presents.

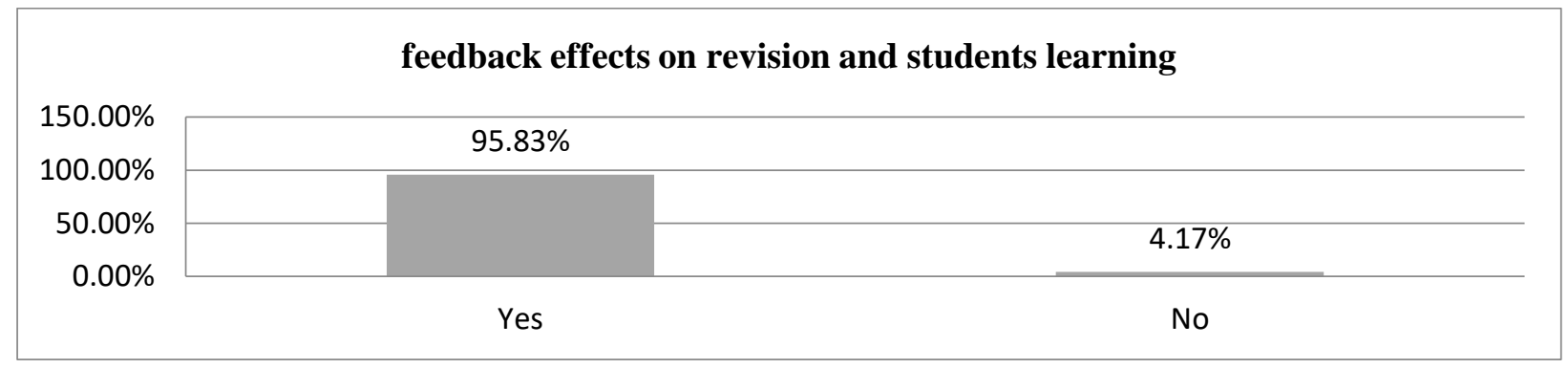

Figure 5: Feedback effects on revision and improves students learning

Source: Field Survey (2020)

From Figure 5, majority of respondents 115 out of 120 representing (95.83\%) indicated that feedback affects revision and improves students' learning while 5 out of 120 indicated that feedback do not affect revision and improves students' learning. The implication of this result is that feedback is useful in revision and improving students' learning. This result is consistent with a study by following studies. Many researchers advocate the importance of feedback in improving the writing skill [Example: Linn \& Miller (2005); Wiliam \& Thompson (2007); Shute (2007); Havnes et al (2012) and Ampofo (2019)]. According to Brookhart (2012) feedback affects revision and improves students learning.

Research Question 2: What are the forms of feedback given to the students by the teachers at New Edubiase Senior High School?

Some of aspect of the questionnaire was to gathered data on the forms of feedback. This is presented below.

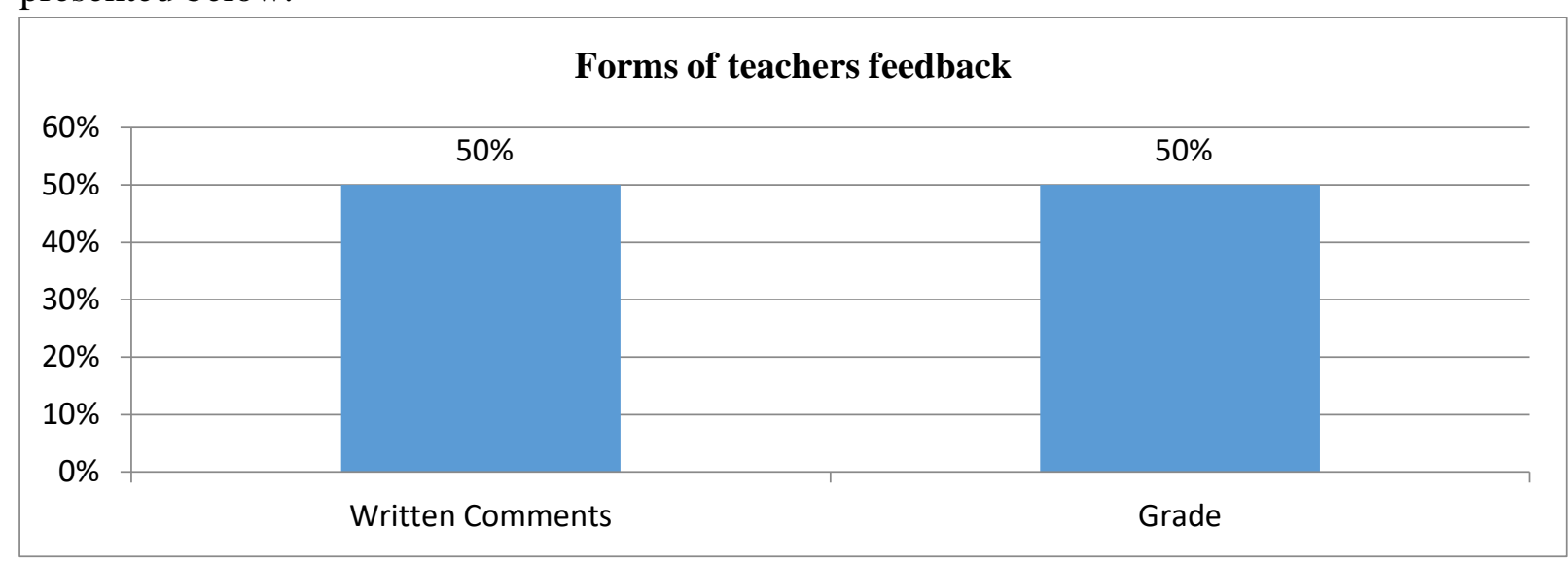

Figure 6: Forms of teachers' feedback

Source: Field Survey (2020)

From Figure 6, 60 out of 120 representing (50.0\%) each indicated that the forms of feedback in New Edubiase Senior High School is both written comments and grades. The implication of this result means that the forms of teachers' feedback given to students in New Edubiase Senior High School are written comments and grade. According to Brookhart (2012) written 
comments and grades as a form of teachers' feedback is the most common feedback delivering method for both teachers and students. Ampofo (2019) asserted that written comments by teachers on students' assessment as a type of feedback may represent the single biggest investment of time by instructors, and it is certainly clear that students highly value and appreciate it.

One aspect of the questionnaire gathered data on what feedback is about. This is what figure 7 presents.

\author{
Teachers feedback is about \\ Feedback on grammer and mechanics $\quad$ Feedback on content
}

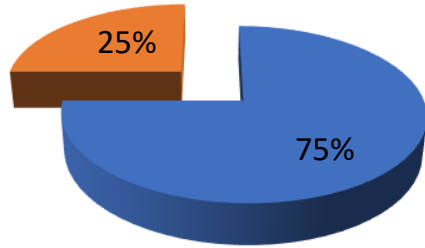

Figure 7: Teachers Feedback is about

Source: Field Survey (2020)

From Figure 7, majority of the respondents 90 out of 120 representing (75\%) indicated that feedback takes the form of grammar and mechanics whiles $30(25 \%)$ indicated that feedback takes the forms of content. This result supports the open ended questionnaire which expresses the respondents' views on what feedback is about. All the respondents agreed to the fact that teachers' feedback focuses on students' background knowledge (only what they have been taught in the classroom) and all aspect of the student knowledge. The implication of this result means that feedback teachers at New Edubiase Senior High School used in their students' assessment are feedback on grammar and mechanics and feedback on content. This result is consistent with a study by Hattie (2012) who introduces a list of the main foci of teacher written feedback. The main foci of feedback adopted from him are: focus on language structures, focus on text functions, focus on creative expression, focus on writing process, focus on content, and focus on genre.

One aspect of the questionnaire also gathered data on how teachers' correct errors spot on student's assessment and this is what Table 10 presents

Table 10

Teachers Comments Spot on Students' Errors in Their Assessment

How do teachers usually comment on errors spot in your students' assessment

\begin{tabular}{cc}
$\begin{array}{c}\text { Frequency } \\
(\mathbf{F})\end{array}$ & $\begin{array}{c}\text { Percentage } \\
(\boldsymbol{\%})\end{array}$ \\
\hline 100 & $83.33 \%$ \\
15 & $12.5 \% \%$ \\
5 & $4.17 \%$ \\
\hline $\mathbf{1 2 0}$ & $\mathbf{1 0 0 \%}$
\end{tabular}

1. Indicate where the error is and correct it for the students

2. Indicate where the error is, what type it is and let the student himself/herself correct it

3. Indicate where the error is using symbols and let the student discover its type and correct it

\title{
Total
}

From Table 10, majority of the respondents 100 out of 120 representing (83.33\%) indicated that teachers comments spot on students' errors indicate where the error is and correct it for 
the students, followed by 15 out of 120 representing $(12.5 \%)$ who indicated that teachers' comments on students errors indicate where the error is, what type it is and let the student himself/herself correct it, followed by 5 out of 120 representing $(4.17 \%)$ who indicated that teachers' comments on students'errors indicate where the error is using symbols and let the student discover its type and correct it.

The implication of this result means that teachers at New Edubiase Senor High School in their assessment of their students' feedback indicate where the error is and correct it for the students and also indicate where the error is, what type it is and let the student himself/herself correct it. This result is consistent with a study by Hattie (2012) who asserted that learning is a process that involves cognitive and social psychological dimensions, and both processes should be considered if academic achievement is to be maximized.

Research Question 3: What impact does teachers' feedback have on the students' academic achievement in school?

Some of aspect of the questionnaire was to gather data teachers' feedback impacts on students' academic achievement in school and the results are presented below.

\section{Praise is an example of postive feeback}

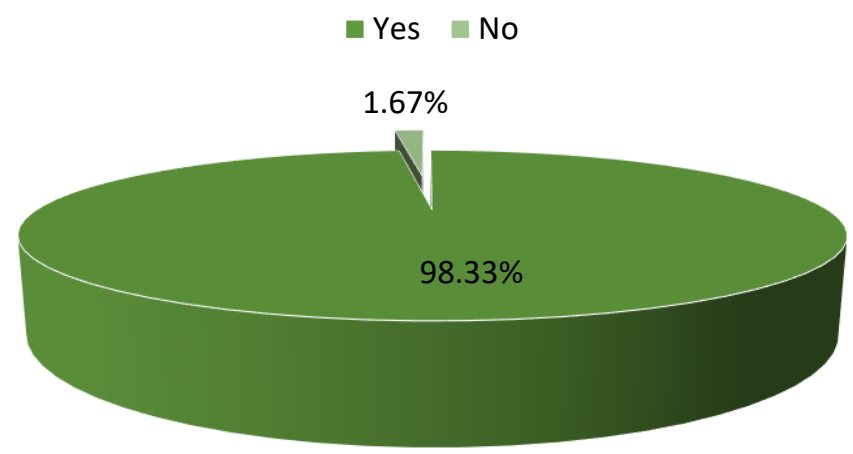

Figure 8: Feedback include positive feedback (example praise)

Source: Field Survey (2020)

From Figure 8, majority of the respondents 118 out of 120 representing (98.33\%) indicated that feedback include positive feedback such as praise while 2 out of 120 representing $(1.67 \%)$ indicated that feedback does not include praise. The implication of this result means that teachers of New Edubiase Senior High School uses praise as feedback when commenting on their students' assessment. This result is consistent with a study by Ampofo (2019) who asserted that students' academic performance is typically assessed and teachers give positive feedback at the end of the assessment to students who perform well.

One aspect of the questionnaire gathered data on how teachers' feedback on students' assessment impact on students' academic achievements and this is what Figure 9 presents. 


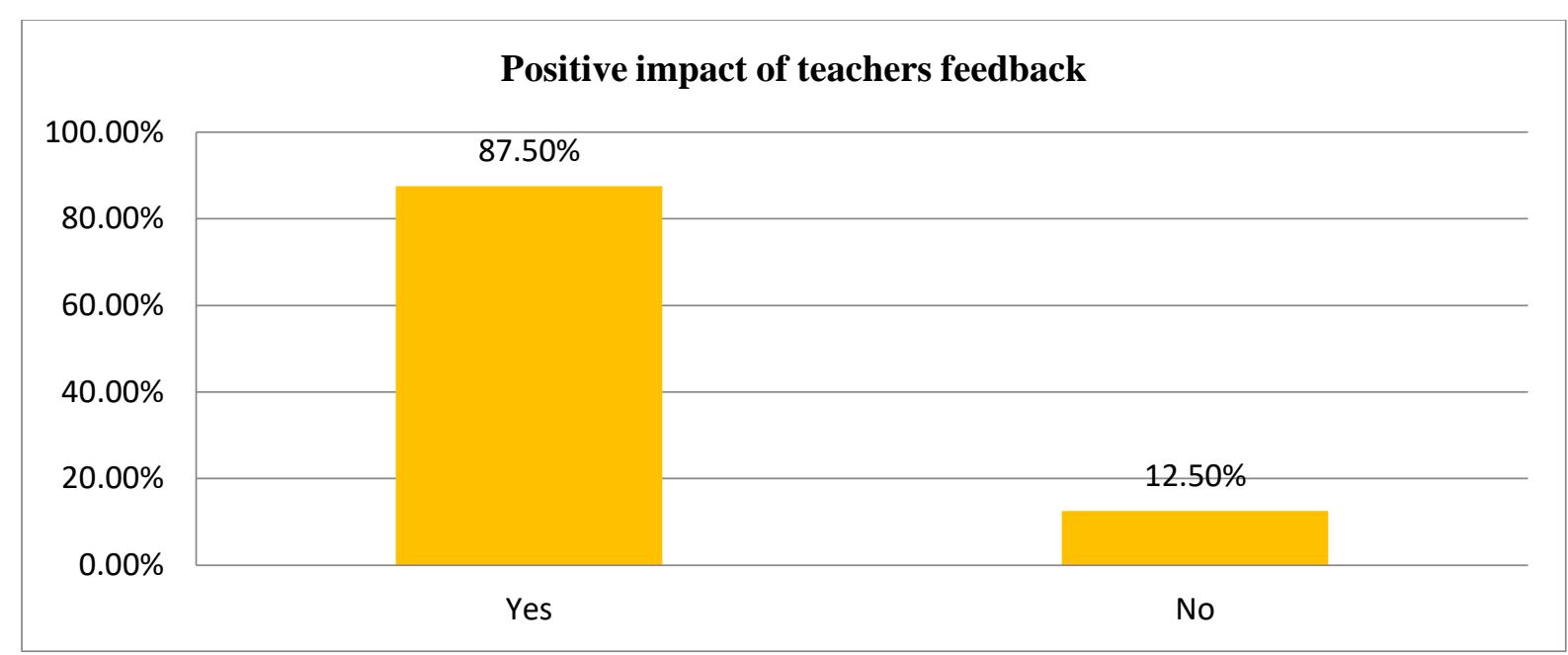

Figure 9: Impact of teachers' feedback on students' academic achievements Source: Field Survey (2020)

From Figure 9, majority of the respondents 105 out of 120 representing $(87.5 \%)$ indicated that teachers' feedback is positive to the academic achievements of students whiles 15 out of 120 representing (12.5\%) indicated that teachers' feedback is not positive to the academic achievements of students. The implication of this result means that teachers' feedback on students' assessment is very important in improving academic achievements of students in New Edubiase Senior High School.

One aspect of the questionnaire also gathered data from respondents on the impact of teachers' feedback on students' academic achievement. This is what table 11 presents.

Table 11

Impact of teachers' feedback on students' academic achievement

\begin{tabular}{|c|c|c|c|c|c|}
\hline $\begin{array}{l}\text { Impact of teachers feedback on students' } \\
\text { academic achievement }\end{array}$ & Agreed & Uncertain & Disagreed & $\mathbf{F}$ & $\%$ \\
\hline $\begin{array}{l}\text { 1. Feedback help students to make } \\
\text { corrections to their assessment }\end{array}$ & $\begin{array}{c}120 \\
(100.0 \%)\end{array}$ & - & - & 120 & 100 \\
\hline $\begin{array}{l}\text { 2. It guides students to do well in later } \\
\text { assessment by teacher }\end{array}$ & $\begin{array}{c}100 \\
(83.33 \%)\end{array}$ & - & $\begin{array}{c}20 \\
(16.67 \%)\end{array}$ & 120 & 100 \\
\hline $\begin{array}{l}\text { 3. It help students to perceive their } \\
\text { teachers scores on their assessment }\end{array}$ & $\begin{array}{c}120 \\
(100.0 \%)\end{array}$ & - & - & 120 & 100 \\
\hline 4. It promote students learning & $\begin{array}{c}120 \\
(100.0 \%)\end{array}$ & - & - & 120 & 100 \\
\hline $\begin{array}{l}\text { 5. It help students to receive information } \\
\text { about their examination }\end{array}$ & $\begin{array}{c}120 \\
(100.0 \%)\end{array}$ & - & - & 120 & 100 \\
\hline $\begin{array}{l}\text { 6. Students feedback should be written } \\
\text { and oral }\end{array}$ & $\begin{array}{c}120 \\
(100.0 \%)\end{array}$ & - & - & 120 & 100 \\
\hline $\begin{array}{l}\text { 7. Teachers feedback should focus on } \\
\text { student strength and weakness }\end{array}$ & $\begin{array}{c}120 \\
(100.0 \%)\end{array}$ & - & - & 120 & 100 \\
\hline
\end{tabular}

Source: Field Survey (2020)

Table 11 shows the impact of teachers' feedback on students' academic achievement. Results in the table indicates that all the respondents $120(100 \%)$ agreed that feedback help students to make corrections to their assessment. Also majority of the respondents 100 (83.33\%) agreed that feedback guides students to do well in later assessment by teachers while $20(16.67 \%)$ disagreed that feedback guides students to do well in later assessment by teachers.

In addition, all the respondents $120(100 \%)$ agreed that feedback help students to perceive their teachers scores on their assessment. Again all the respondents $120(100 \%)$ agreed that 
feedback help students to receive information about their examination. Also all the respondents $120(100 \%)$ agreed that students' feedback should be written and oral. All the respondents $120(100 \%)$ agreed that teachers' feedback should focus on student strength and weakness. The implication of all these result means that teachers' feedback is relevant in students learning.

According to Havnes et al (2012) feedback should be selective, building on what is presently significant to students and giving attention to what has been taught in the classroom. The result of this study is consistent with a study by Rakoczy et al (2013) who asserted that providing feedback on students' writing is extremely important. Thurlings et al (2013) highlights the importance of positive feedback in pedagogical settings due to the purposes it serves; on the one hand, it supports the learner or students to make corrections to their assessment and guides students to do well in later assessment by teacher. The result of this study also confirms to the findings by Wiggins (2012) who asserted that feedback help students to receive information about their examination which intends promote students learning thereby enhancing the academic achievement of students.

\section{MAJOR FINDINGS OF THE STUDY}

A descriptive survey was employed for the study. A questionnaire was used to gather data from the students and teachers of New Edubiase Senior High School and selected through stratified and purposive random sampling. The collected data was analyzed in simple percentages and figures.

The first research question was to find out whether students of New Edubiase Senior High School are aware of the importance of the teachers' feedback. The study found out that students of New Edubiase Senior High School are aware of the importance of teachers' feedback. It also emerged from the study that the most useful technique of assessing students of New Edubiase Senior High School by their teachers is formative assessment. The study also found out that both formal and informal type of formative assessment is used in assessing students of New Edubiase Senior High School by their teachers but the type of formative assessment that is mostly used in assessing students is formal.

The study also found out that students are always and sometimes provided with immediate feedback after any sort of assessment. The study also found out that feedback promote students learning, help students to know the benefit of learning, encourages students to be more active and participate in class activities, help students to internalize and process the demands of task given to them by their teachers, increases self-esteem of students, guides students in on their performance, deepen the understanding of students on their performance and also clarify what students should do.

The second research question was to find out the forms of feedback given to students by the teachers in the school. It emerged from the study that the forms of feedback used by teachers of New Edubiase Senior High School is written comments and grades. The study also found out that teachers of New Edubiase Senior High School feedback is about students' grammar and mechanics and content knowledge of students. The study also found out teachers when commenting on students on students' assessment mostly indicate where the error is and correct it for the students, indicate where the error is, what type it is and let the student himself/herself correct it and also indicate where the error is using symbols and let the student discover its type and correct it 
The third research question was to find out the impact of teachers' feedback on students' academic achievement. The study found out that teachers of New Edubiase Senior High School feedback impact positively their students thereby improving their academic achievement. It also emerged from the study that feedback help students to make corrections to their assessment, guides students to do well in later assessment by teacher, help students to perceive their teachers scores on their assessment, promote students learning and also help students to receive information about their examination.

\section{CONCLUSIONS}

Based on the findings of the study, the following conclusions could be drawn.

Students of New Edubiase Senior High School are aware of the importance of teachers' feedback. The study also concludes that formative assessment is the most common technique teachers of New Edubiase Senior High School use in assessing their students. The study further concludes that students of New Edubiase Senior High School are always and sometimes provided with immediate feedback after any sort of assessment from their teachers. It can also be concluded form the findings of this study that teachers of New Edubiase Senior High School feedback promote students learning, help students to know the benefit of learning, encourages students to be more active and participate in class activities, help students to internalize and process the demands of task given to them by their teachers, increases self-esteem of students, guides students in on their performance, deepen the understanding of students on their performance and also simply and clarify what students should do.

Moreover, the study concludes that teachers of New Edubiase Senior High School when commenting on students' assessment mostly indicate where the error is, what type it is and let the student himself/herself correct it and also indicate where the error is using symbols and let the student discover its type and correct it.

Lastly the study concludes that for there to be an improvement in the academic achievement of students of New Edubiase Senior High School their teachers feedback should be written and oral, teachers feedback should focus on student strength and weakness teachers, teachers written feedback should focus on grammar and mechanics, teachers' written feedback should focus on grammar, mechanics and content, teachers' written feedback should be direct (detailed), teachers' written feedback should be indirect (codes/symbols), teachers' written feedback should include praise as well as critic, teachers' written feedback should include grades and lastly teachers' feedback should be understandable by students.

\section{RECOMMENDATIONS}

From the findings of this study, the researcher strongly recommends that the government of Ghana, through the Ministry of Education and the Ghana Education Service make it a must for teachers to give feedback on students' assessment.

All teachers of New Edubiase Senior High School should see the importance of feedback on students' academic achievement as such their feedback on students' performance should be understandable by students, teachers' written feedback should include praise as well as critic, teachers' written feedback should focus on grammar and mechanics, teachers' written feedback should focus on content, teachers' written feedback should focus on grammar, mechanics, and content as such enhancing the academic achievement of their students in all subjects. 
Finally, the study recommends that teachers of New Edubiase Senior High School should use formative feedback effectively as an effective tool on student learning and student achievement and must also see the importance of assessment and clearly show how feedback can have a positive impact on student learning.

\section{Acknowledgements}

The research team wants to thank the editorial board of Fair East Publishers and also Antwi Abrefi Abigail (Law student at University of Professional Studies, Accra, Ghana) and Agartha Maame Yaa Antwi (Graduate from the University of Education, Winneba, Ghana) for their sound support and excellent contributions.

\section{Conflict of Interest Statement}

No conflict of interest has been declared by the author.

\section{Funding}

The researcher has not received any support for the publication of this paper.

\section{References}

Ajogbeje, O. J. (2012). Path-analytic model and the effect of some teaching strategies on variables affecting achievement in junior secondary school mathematics in ondo state. Unpublished Ph D. Thesis, Ekiti StateUniversity, Ado-Ekiti, Nigeria.

Ampofo, A. J. (2020). Challenges of Student Management Information System (MIS) in Ghana: A case study of University for Development Studies, Wa Campus. International Journal of Management \& Entrepreneurship Research, 2(5), 332-343.

Ampofo, A. J. (2020). Contributions of the hospitality industry (hotels) in the development of Wa. International Journal of Advanced Economics, 2(2), 21-38.

Ampofo, A. J. (2020). Implications of poor waste disposal management practices on senior high schools within the Wa Municipality of Ghana. International Journal of Applied Research in Social Sciences, 2(3), 53-70.

Ampofo, A. J. (2020). The nature of mortgage repayment plans in Ghana. Finance \& Accounting Research Journal, 2(3), 91-104.

Ampofo, A. J. (2020). Rural housing challenges in the Upper West Region of Ghana: A case study of Kulmasa. International Journal of Management \& Entrepreneurship Research, 2(4), 194-211.

Ampofo, A. J. (2019). Reading difficulties among class six pupils of Wa Basic School Complex: Lambert Academic Publishing.

Ampofo, A. J. (2019). Performance management and appraisal in improving teachers quality: Lambert Academic Publishing.

Brookhart, S. (2012). Preventing feedback fizzle. Educational Leadership: Feedback for Learning, 70(1), 25-29.

Creswell, J.W. (2013). Qualitative inquiry and research design: Choosing among five approaches $\left(3^{\text {rd }}\right.$ edn.). Thousand Oaks: Sage.

Hattie, J. (2003). Teachers make a difference: what is the research evidence?. Camberwell: Australian Council for Educational Research. 
Hattie, J. (2009). Visible learning: A synthesis of over 800 meta-analyses relating to achievement. New York: Routledge.

Hattie, J. (2012). Know thy impact. Educational Leadership: Feedback for Learning, 70(1), 18-23.

Havnes, A., Smith, K., Dysthe, O., \& Ludvigsen, K. (2012). Formative assessment and feedback:Making learning visible. Studies in Educational Evaluation, 38, 21-27.

Kusi, H. (2012). Doing qualitative research, a guide for researchers. Accra: Emmpong Press

Linn, R. L., \& Miller, M. D. (2005).Measurement and assessment in teaching (9th ed.). Upper Saddle River, NJ: Pearson Prentice Hall.

Rakoczy, K., Harks, B., Klieme, E., Blum, W., \& Hochweber, J. (2013). Written feedback in mathematics: Mediated by students' perception, moderated by goal orientation. Learning and Instruction, 27, 63-73.

Sendziuk, P. (2010). Sink or Swim? Improving student learning through feedback and self assessment. International Journal of Teaching and Learning in Higher Education, 22(3), 320-330.

Shute, V. J. (2007). Tensions, trends, tools, and technologies: Time for an educational sea change. In C. A. Dwyer (Ed.), The future of assessment: Shaping teaching and learning. Mahwah, NJ: Lawrence Erlbaum Associates.

Strijbos, J. W., Narciss, S., \& Dunnebier, K. (2010). Peer feedback content and sender's competence level in academic writing revision tasks: Are they critical for feedback perceptions and efficiency?. Learning and Instruction, 20, 291-303.

Thurlings, M., Vermeulen, M., Bastiaens, T., \& Stijnen, S. (2013). Understanding feedback: A learning theory perspective. Educational Research Review, 9, 1-15.

Wiggins, G. (2012). Seven keys to effective feedback. Educational Leadership: Feedback for Learning, 70(1), 10-16.

Wiliam, D., \& Thompson, M. (2007). Integrating assessment with instruction: What will it take to make it work? In C. A. Dwyer (Ed.), The future of assessment: Shaping teaching and learning. Mahwah, NJ: Lawrence Erlb 